\title{
Dual board system under German company law
}

by Frank Wooldridge

German Aktiengesellchaften have had a dual board system consisting of a management and supervisory board (Vorstand and Aufsichtsrat) since 1970. The present article will outline some of the principal rules contained in the Aktiengesetz concerning such boards of public companies, and will also make occasional reference to the German Corporate Governance Code which is applicable to German listed companies (para $161 \mathrm{AktG}$ ): other German public companies are free to adopt the Code which contains recommendations (Empfehlungen) which should be complied with, or some explanation be given for non compliance in the company's annual report. Other provisions of the Code contain suggestions, or set out what appears to be the position under German law governing certain matters. The legal effect of the recommendations in the Code gives rise to considerable uncertainty.

$\mathrm{T}$ he dual board system has undergone some criticism in Germany in recent years, as also have the systems of paritative (equal) and quasi-paritative codetermination in the supervisory board. The former system of codetermination is made applicable to companies in the coal, iron and steel industries having more than 1,000 employees by the Works Council Act 1952 and is now declining importance. The quasiparitative system of codetermination was introduced by the Codetermination Act 1976, which does not apply to companies governed by other codetermination statutes, or to companies which serve political, trade union, religious, charitable, scientific or artistic purposes, or which involve the media (para 1(3) and (4), Codetermination Act 1976). A further system of codetermination is made applicable to companies having between 500-2000 employees and which are not engaged in the coal, iron and steel industries under the Codetermination Act of 2004 (one third employee participation statute). Companies having less than 500 employees do not come within that Act if they are family controlled. The size of the supervisory board of companies is regulated by paragraph $95 \mathrm{Akt} G$ to the extent that there are no conflicting provisions in the Coal, Iron and Steel Codetermination Act 1951 or the Codetermination Act 1976.

The 1976 Act applies to public and private companies, limited partnership with shares (Kommanditgesellschaften auf Aktien), and cooperatives (Genossenschaften) under the 1976 Act. The maximum size of the supervisory board is 20, where the company has more than 20,000 employees. If the number of employees is between 2,000-10,000, it is
12 , if the number is between 10,000-20,000, it is 16 . (para 7(1), No3, ibid). The supervisory board is regulated by paragraph $95 A k t G$ to the extent that there are no conflicting provisions it consists of an equal number of employees and shareholders representatives. The chairperson, who is usually a representative of the employees, has a casting vote (para 31(4), Codetermination Act 1976). The representatives of the employees on the board consist of employees of the company and trade union representatives (para 7(2), ibid). The election of the employees representative may take place by a direct method, or through the medium of delegation.

Under the system of codetermination in the coal, iron and steel industries, the supervisory board is made up of an equal number of shareholders, and employees representatives and an independent chairperson. An attempt is made by paragraph 4 of the 1951 Act to secure the neutrality of certain members of the board. The number of members of the supervisory board maybe 21 , where the company has a share capital of more than 25 million euros. When the Works Councils Act of 1952 is applicable, the representatives of the employees comprise one third of the members of the supervisory board (para $76(1)$, ibid). They are elected by a system of direct and secret voting (para 76(2), ibid). The rules contained in paragraph $95 A k t G$, which are considered below, govern the number of its members (para 77(1), Works Councils Act 1952).

It has frequently been contended in recent years that members of supervisory boards may serve on too many 
such bodies, lack adequate experience and devote insufficient time to their duties. This may be particularly the case with shareholders' representatives, who are elected by the shareholders (para 101(1) $A k t G$ ). Criticisms of the paritative systems of codetermination have been made on the grounds that supervisory boards set up under the Acts of 1951 and 1976 often discuss employment and related matters to the detriment of exercising their task of supervision; that employees representatives on such boards may be too much influenced by trade unions, and that a board may be of an unwieldy size, thus inhibiting meaningful discussion. However, as is the case with the dual board system, the systems of paritative codetermination are likely to remain in existence in Germany in the immediate future. The appointment dismissal, composition and functions of the boards of a German public company receives further consideration below.

\section{THE MANAGEMENT BOARD}

\section{Role: appointment and dismissal of members}

The management board is entrusted with responsibility for management (Leitung) of the company by paragraph 76(1) $A k t G$. The board may, according to paragraph 76(2) $A k t G$ consist of one or more persons: if the share capital exceeds 3 million euros, it shall consist of at least two, unless the statutes otherwise provide. Managerial responsibilities (Massnahmen der Geschäftsführung) may not, in principle, be conferred on the supervisory board. (para 111(4) No $1 \mathrm{AktG}$.) Nevertheless, paragraph 111(4) No2 $A k t G$ stipulates that the statutes or the supervisory board must provide that specific types of transactions may only be entered into with the consent of the supervisory board. However, if the board refuses its consent, the general meeting may override its decision. The management board loses its sole responsibility for managing the company where the latter is subject to the directions of another company under a control agreement, or is integrated with a principal company.

The concept of management (Leitung) under German law appears narrower than that of Geschäftsführung (conduct of the affairs) used in paragraph 77 of, and elsewhere in, the Aktiengesetz. The latter concept seems clearly intended to include management. It would also appear to include such matters as carrying on strategic planning, coordinating the work of different departments, determining important policy matters, the exercise of controlling functions, and the employment of staff.

The members of the management board are appointed by the supervisory board for a period of up to five years (para 84(1) $A k t G$ ) . Paragraph 5.1.2 of the Corporate Governance Code understandably recommends a shorter period of time for first appointments. If the company is governed by the Coal, Iron and Steel Codetermination Act 1951 or by the Codetermination Act 1976, it follows from paragraph 13 of the former Act and paragraph 33 of the latter one that a labour director (Arbeitsdirektor) must be appointed, who is required to carry on his or her tasks in cooperation with the other members of the board. The latter may work on a collegiate basis, but as in many other countries, divisionalisation is common in Germany, especially in large undertakings. The number of members of the board must be at least two (which will include any Arbeitsdirektor) if the company's nominal capital is more than 3 million euros, unless the statutes provide otherwise (para 76(2)AktG).

Members of the management board must be natural persons having full legal capacity, and must not have been convicted of any crime involving insolvency during the past five years, or have been prohibited from engaging in a trade or profession where the company's purpose (Unternehmensgegenstand) partly or wholly involves the prohibited activity (para 76(3) $A k t G$ ). A member of the supervisory board may not be a member of the management board, or the permanent deputy of a member of that board (para 105(1) $A k t G$ ). However, according to paragraph 105(7) $A k t G$, the supervisory board may appoint certain of its members as deputies for absent or incapacitated members for a stipulated period which must not exceed one year. Such persons may not serve on the supervisory board during the relevant period (para 105(2) $A k t G)$.

The supervisory board may only revoke an appointment to the management board, or to the chair of such a board for good cause. This is treated by paragraph 84(3) $A k t G$ as present where there has been a serious breach of duty by a board member or such a member is unable to carry on the affairs of the company; or the general meeting has expressed its lack of confidence in him, unless such a vote of no confidence is motivated by clearly arbitrary reasons. Such revocation may be challenged in the courts (para 84(3) $A k t G$ ). Where the company is subject to the Coal, Iron and Steel Codetermination Act 1951, it follows from paragraphs 13(1) and (2) of that Act that the labour director cannot have his appointment terminated (not indeed be appointed) unless the majority of the employees' representatives on the supervisory board vote in favour of such action.

\section{Rules governing management and representation}

Paragraphs 77 and $78 \mathrm{Akt} G$ contain rules governing the management and representation of public companies. The management board of a public company represents that company both in and out of court. Unless the statutes otherwise provide, the conduct of the company's affairs and its representation in relation to outsiders is entrusted to the management board, acting jointly. It commonly happens that the conduct of the company's affairs and its representation is entrusted to one or more members of the board, or to one member acting together with an authorised agent called a Prokurist. Sometimes the statutes 
or the company's by-laws (Geschäftsordnung) may give a particular member of the board, frequently the chairman, the right to block a decision, sometimes with a temporary effect. While a company is subject to the Codetermination Act 1976, the grant to a right to permanently block a decision may be incompatible with the position given to the labour director under paragraph 33 of the Act.

The chairperson is frequently given a casting vote. The names of members of the management board are required to be entered in the Commercial Register by paragraph 81 $A k t G$.

\section{Remuneration and participated in profits}

Profit participation by members of the management board is governed by paragraph $86 A k t G$. Their remuneration is dealt with (perhaps somewhat sketchily) by paragraph 87 , and there are a number of recommendations concerning such remuneration in paragraphs 4.2.2-4.2.4 of the Corporate Governance Code. A considerable number of amendments to the Code's provisions concerning remuneration were made in 2003. According to paragraph $87 A k t G$, the supervisory board is required to ensure that the aggregate remuneration of any member of the management board bears a satisfactory relationship to the duties of such a member, and the position of the company. The same rule is made applicable by way of analogy to pensions, payments to surviving dependants and comparable payments. Remuneration may be reduced by the Court on the motion of the supervisory board if its payment to a member of the management board would result in serious hardship for the company. It is noteworthy that paragraph 4.2.4 of the Corporate Governance Code recommends the disclosure of the remuneration of the members of the management board subdivided into fixed, performance related and longterm incentive payments, which should be individualised in the notes to the accounts. This recommendation has not generally been complied with by large companies, and the present matter may come to be regulated by a specific statutory provision. If companies do not comply with the relevant Code provision in the future.

\section{Duties and liabilities}

Paragraph 88(1) $A k t G$ provides that unless the supervisory board gives its consent, members of the management board may neither engage in any trade nor enter into any transaction in the same field of business as that company either on their own behalf or on that of others. As far as listed companies are concerned, the above rule is supplemented by those of paragraph 4.3.1-4.3.5 of the Corporate Governance Code consuming conflicts of interest. Thus, for example, paragraph 4.3.1 of the Code provides that during their employment for the enterprise, members of the management board are subject to a comprehensive non-competition obligation, whilst paragraph 4.3 .5 provides that members of the supervisory board shall take in subsidiary activities especially supervisory board mandates outside the undertakings only with the approval of its supervisory board. The extension of credit to members of the management board and their spouses, partners or minor children also requires the approval of the supervisory board. Credit extended in violation of these provisions has to be repaid immediately, unless the supervisory board subsequently consents (para 89, $A k t G)$.

The supervisory board and its chairperson have extensive rights to receive reports on a number of matters set out in paragraph $90 \mathrm{Akt} G$, which was amended by the Control and Transparency Act 1998 (BGBl 1.1998,786). Such reports concern (inter alia) the intended business policy of the company and other fundamental matters relating to its future strategy, and in particular, its finance, investment and personnel plans. The management board is also required to report on transactions which may have a significant impact on the profitability or solvency of the company, and report also on subsidiary companies. As far as listed companies are concerned, paragraph 34 of the Corporate Governance Code provides that the management board informs the supervisory board regularly, without delay, and comprehensively of all issues important to the enterprise with regard to planning business developments, risk situations or risk developments. The management board points out deviations of the actual business development from previously formulated plans and targets, indicating the reasons therefore. This provision appears intended to specify the existing legal position, and not to constitute a recommendation.

Paragraph 91(1) $A k t G$ provides that the management board shall ensure that the necessary account books are kept. The board is required by paragraph 91(2) to take suitable measures for the early recognition of development endangering the future existence of the company.

The management board is responsible for calling meetings of the company, which may also be called at the request of a minority holding at least one-twentieth of the nominal capital (paras 121 and $122 A k t G$ ). The board is required to call a meeting if it becomes evident from an annual or interim balance sheet that the company has suffered a loss equal to one half of its nominal capital. The management board is required to file a petition for insolvency proceedings without delay and must apply to the court within three weeks of the company's becoming unable to make payments when due or becoming overindebted (Überschuldet) (para 92(2) AktG). Overindebtedness is deemed to occur when a company's liabilities are no longer covered by its assets.

The provisions of paragraph $92 A k t G$ concerning the duty of care and liability of members of the management board are complex and have given rise to some controversy. Paragraph 93(1) provides that in conducting business the 
management board shall exercise the care of a diligent and conscientious manager. They shall not disclose confidential information or secrets of the company, especially trade or business secrets of which they have become aware by reason of their service on the management board. The general clause in paragraph 93(1) sentence $1 A k t G$ is thought to be applicable to all the duties of directors, for example in relation to their managerial responsibilities, their fiduciary duties and duties imposed on them by specific provisions of the Aktiengesetz (note for example paras $80,81,83,88,91(2)$ and 92 thereof). The standard is not that of an ordinary businessman, but that of a person in a responsible and leading position as the manager of other persons property in a particular undertaking. The standard is an objective one, and inability or inexperience are not treated as excuses. A member of the management board of a company who has particular functions allotted to him under the statutes or otherwise is not only responsible for his own sphere of activity, but he is also expected to exercise supervision over his fellow directors.

Paragraph 93(1) sentence $2 A k t G$ applies to all the members of the management board, including the labour director (Arbeitsdirektor) if any, as well as, deputies appointed by the supervisory board under paragraph 105(2) AktG. It applies to processes of manufacture of production, financial planning, regular customers, and important decisions relating to employees. A general clause concerning the liability of members of the management board is contained in paragraph 93(2) $A k t G$. This provision stipulates that members of the management board who breach their duties shall be jointly and severally liable to the company for any resulting damage. If there is a dispute as to whether or not they have employed the standard of care of a diligent and conscientious manager, they shall bear the burden of proof. Damage is presumed to be caused in the nine situations set out in paragraph 93(3) $A k t G$.

If a company brings an action under paragraph 93 it will be required to produce evidence of acts of the directors which have caused damages; as already indicated, damage is presumed to have occurred in the special cases set out in paragraph 93(3) $A k t G$, but in other cases the company must be shown by the plaintiff to have been suffered by reason of act or omission of a director which may be a breach of duty to the satisfaction of the court. According to some writers, the reversal of the normal burden of proof under German law only requires the defendant director to show that he has not been guilty of subjective fault, ie conduct deserving of blame; however the predominant opinion seems to be that the defendant has also to demonstrate that he has exercised the necessary care (see the discussion in Lutter and Hommelhoff, GmbH Gesetz, 15 $5^{\text {th }}$ ed., pub. Verlag Dr Otto Schmidt, Köln 2000, p 683). According to an article by Goette in Zeitschrift für Gesellschaftsrecht 1945 (at p648) which has frequently been cited, the director may escape liability by demonstrating that he has fulfilled his duties, or has been responsible for subjective fault, or that the damage would still have been suffered if he had performed his duties. In the Arag Garmenbeck case (BGHZ $134,24)$ the Supreme Court held that the directors are not liable if they acted in the interests of the company and on the basis of adequate information.

According to paragraph 93(4) $A k t G$, the liability of members of the managing board is not excluded by the approval of a transaction by the supervisory board, but it is excluded if the transaction was approved by a lawful resolution of the shareholders' meeting. Paragraph 93(5) $A k t G$ permits the claim of the company to be asserted by the company's creditors if they are unable to obtain satisfaction from the company.

\section{THE SUPERVISORY BOARD}

\section{Appointment and dismissal of members}

As explained above, the task of the Aufsichtsrat is to supervise the management board and in principle, managerial tasks may not be conferred on it. Except where there are conflicting provisions in one of the Codetermination Acts the board must comprise three members, unless the statutes provide for a higher number, which must be divisible by three. The maximum number of nine if the capital is 1,500,000 euros or less; 15 if the capital is more than 1,500, 000 euros; and 21 if it exceeds $10,000,000$ euros. The special rules contained in the Codetermination Acts have been considered above.

Under the system of codetermination governed by the 1967 Act, the method of election of employees' representatives is very complex. The numbers of employees and shareholders representatives, which are equal, vary in accordance with the size of the workforce. The representatives of the employees in the supervisory board always include some representatives of a trade union represented in the company, or in another company whose employees participate in the election of the employees representatives in the board of the former company. There are basically two types of election. If the undertaking has less than 8,000 employees, direct elections take place, unless the employees who are qualified to note down that if the election shall take place through the medium of delegates (para 9(2), Codetermination Act 1976). If the undertaking has more than 8,000 employees the election will take place through the medium of delegates representing the employees unless employees qualified to vote decide upon direct election (para 9(1), ibid). A vote on the question of the method of election must be requested by a motion signed by one twentieth of the workforce of the undertaking. The relevant decision must be taken by at least half the workforce qualified to vote. The ballot is secret (para 9(3), ibid). Voting takes place by a system of proportional representation, unless only one nomination is made, when the candidates are chosen by a majority vote. In such a case, the number of candidates must be twice the member of vacant seats (paras 15 and 18, ibid). 
The trade union representatives are chosen by means of a secret ballot of delegates representing the employees. The candidates may be nominated by the trade unions represented in the undertaking or in other undertakings which belong to the same group as the controlling undertaking, and whose employees participate in the choice of the members of the latter undertaking's supervisory board. Should only one nomination be made, the trade union representatives are chosen by a majority vote rather than by proportional representation (para 16, ibid).

Most decisions of a supervisory board set up according to the quasi-paritative system of codetermination provided for by the 1976 Act require a simple majority. However, a two-thirds majority is required in the cases set out in paragraphs 27, 29 and 31(2) of the Act. By paragraph 27 of the Act, the chairperson of the supervisory board must be elected by a two thirds majority of the members. Where such a majority cannot be attained, the shareholders representatives, who are elected by the general meeting (para 101 (1) and (2) $A k t G$ ) elect the chairperson; and the employees representatives the vice chairperson (para 27 of the Codetermination Act 1976). This rule explains why the chairperson, who has a casting vote (para 29(2) Codetermination Act 1976), is usually a representative of the shareholders, such that really paritative codetermination is not attained.

Such parity is obtained when the Coal, Iron and Steel Codetermination Act 1951 applies. Under this system, the neutral chairperson is elected by a majority vote of the shareholders' and employees' representatives (para 8(1), ibid). If the supervisory board has 11 members (it may have 15 or 21 in certain circumstances) at least two of them must belong to the workforce of the company and two may, and usually do belong to unions represented in the undertaking. The fifth member additional to the former ones must not belong to a trade union or employers association, or have a service agreement with, or be any employee of the company, or employ persons on its behalf, or have a significant interest in it. The same rule applies to the neutral chairperson and the person additional to the four shareholders representatives. Proposals for the appointment of employees' representatives other than the two who belong to the workforce must be made by the executive organs of the relevant trade unions, after making consultations with their representatives in the undertaking. The actual nomination of the employees' representatives is left to the works Council: the competent organ of the company is bound by them in accordance with paragraph 6 of the Coal, Iron and Steel Codetermination Act 1951. According to paragraph 6 of the 1951 Act, the shareholders representatives are appointed by the competent organ of the company as provided by the law or the statutes: this would most usually be the general meeting.

When codetermination in the supervisory board is governed by the Codetermination Act 2004, it is provided by paragraph 5 of Part II of that Act that the employees' representatives on the supervisory board are elected by a secret and direct vote of all the employees in the undertaking over the age of 18 . Nominations may be made by the works councils and by at least one tenth of the eligible employees of the undertaking, by a minimum of 100 employees (para 6 of Part II of the Codetermination Act 2004).

As already indicated, in principle the election of the shareholders' representatives on the supervisory board takes place in the general meeting. However, the statutes may provide that a maximum of one-third of the shareholders' representatives may be appointed by shareholders specified in the statutes, or by shareholders who have particular registered shares which may only be transferred with the consent of the company (para 101(1) and (2) $A k t G$ ). Members of a supervisory board may not be appointed for a period in excess of approximately five years; they must be natural persons. An individual may not serve on more than ten supervisory boards. A person is not eligible for membership of a supervisory board who is the legal representative of a dependent company of the relevant company, or the legal representative of another undertaking whose supervisory board included a member of the company's management board (para 100(2) Nos 2 and $3 A k t G)$.

As in the case with non-executive directors in the United Kingdom, there has been some criticism of the quality of some members of the supervisory boards of German public companies. Paragraph 5.4.1 of the German Corporate Governance Code contains recommendations designed to ensure that members of the supervisory board are of suitable calibre. The Code also recommends that members of the management board of a listed company shall not accept more than a total of five supervisory board posts in non-group listed companies (para 5.4.3 ibid). This provision reminds one that there is nothing to prevent former chairpersons or members of the management board, from becoming members of the supervisory board of the same company.

Members of the supervisory board may resign or be removed from office. The removal of members elected by the shareholders' meeting which has not been bound by nominations normally requires a majority of at least three fourths of the votes cast of the general meeting, but more stringent conditions may be imposed (para 103(1) AktG). In the case of particular members elected in accordance with or designated by the statutes, such members may be removed by those responsible for their election or designation. Designated members may be removed by a simple majority of the votes at the general meeting if they cease to fulfil the requirements of the statutes (para 103(2) $A k t G$ ). A member of the supervisory board may be removed for good cause by the court on the application of the supervisory board acting by a simple majority. This rule is applicable to all the members of the supervisory board 
and thus to elected or designated members, and to those who represent the employees and those who represent the shareholders (para 103(3) $A k t G$ ).

Members of the supervisory board who are not appointed by the general meeting or in accordance with the statutes, but instead under one of the Codetermination Acts may be removed under the provisions of the relevant Act (see para 103(4) AktG; para 23 Codetermination Act 1976; para 10 Coal, Iron and Steel Codetermination Act 1951; and para 76 Works Councils Act 1952).

The appointment of members of the supervisory board to cover vacancies when a quorum cannot be constituted is governed by the detailed provisions of paragraph $104 \mathrm{Akt} G$. According to paragraph $105 \mathrm{AktG}$, a member of the supervisory board may not be a member of the management board, or a permanent deputy member thereof.

\section{Remuneration and loans}

According to paragraph $113 \mathrm{Akt} G$, the members of the supervisory board may receive remuneration for their services, which may be determined in the statutes or by the shareholders' meeting. Such remuneration must bear a reasonable relationship to the duties of the members of the supervisory board and the position of the company. If the remuneration is determined in the statutes, the shareholders' meeting may, by a simple majority, resolve on the amendment of the statutes so as to reduce the remuneration.

Paragraph 5.4,5 of the Corporate Governance Code repeats much of what is contained in Article 113. However it recommends that the exercise of the chairmanship and deputy chairmanship of the board and its committees should be taken into account. It is also recommended by paragraph 5.4,5 that members of the board shall receive fixed and performance related remuneration: the latter should contain elements based upon the long term performance of the undertaking. The separation into fixed and performance related components of the remuneration appears to occur in practice.

It was held in a recent decision of the Supreme Court (Bundesgerichtshof) that the grant of stock options to members of the supervisory board was incompatible with the Aktiengesetz because of the possible danger of conflicts of interest (see BGH judgment of February 16, 2004 IIZR 316/02, [2004] Die AG 265).

The grant of credit to members of the supervisory board and to spouses, partners and minor children thereof may only take place with the consent of the board (paras 115(1) and (2) $A k t G$ ). Agreements between members of the supervisory board and the company for the provision of professional services which do not give rise to an employment relationship, or an undertaking to perform a special task require the consent of the supervisory board if they are to be valid (para $114 \mathrm{Akt} G$ ).

\section{Procedural rules}

The supervisory board decides by resolution. Insofar as the quorum is not determined by law, it may be by the statutes (paras 108(1) and (2) AktG). Members may act in person and in writing, but may not appoint a representatives to function in their absence (paras 108(3) and 111/5 AktG). However, according to paragraph 101(3) $A k t G$ a substitute member may be appointed for each member of the supervisory board to replace them if they cease to hold office prematurely. By paragraph 107(1), the supervisory board is required to elect a chairperson and a deputy chairperson, who has the right and duties of the chairperson only if the latter is incapacitated.

Meetings of the supervisory board should be called once in every calendar quarter and must be called in every halfyear. In the case of a listed company, they must be called twice in each calendar half year (para 110(3) AktG). Furthermore, every member of the supervisory board or management board may, upon stating the grounds for such actions ask the chairperson of the supervisory board to promptly call a meeting of that board (para 110(1) AktG). The view has been taken that meetings of the board are insufficiently frequent. However, certain of the work of the board may be done by the chairperson or by committees thereof. Criticisms of the management are often dealt with in practice by internal discussions between shareholders' representatives on the supervisory board and the management

Unless one of the Codetermination Acts applies, quorums of the board may be provided for by the company's statutes. If the quorum is not stipulated by the law or by the statutes, it consists of at least one half of the number of the board, or at least three members thereof (para 108(3) Aktg). Members of the board should not exercise a vote on transactions in which they have a personal interest. Paragraph 5.5.2 of the Corporate Governance Code recommends that each member of the board shall inform it of any conflicts of interest which may result from a consultancy or directorship with clients, suppliers, lenders or other business partners.

The board may form committees in particular for the purpose of preparing its deliberations and resolutions and supervising the execution of the latter. Certain matters may not, however, be delegated to a committee: these include the appointment of the chairperson or deputy chairperson; the advance payment of distributable profits; the appointment and removal of members of the management board; the appointment and removal of members of the management board; the calling or a shareholders' meeting; the examination of the financial statements and of the annual report on relations with connected companies (verbundene Unternehmen) (para 107(3) Akt G. The formation 
of an audit committee is recommended by paragraph 5.1.2. of the Corporate Governance Code. Paragraph 5.3.3 of the Code, which is evidently intended to state the existing legal position says that the supervisory board can delegate questions of the strategy or the undertaking, the composition of the members of the management board, and investment and financing to committees. Audit committees, as well as nomination and remuneration committees, are increasingly used by German listed companies.

Functions of the supervisory board and the chairperson

As already indicated above the supervisory board is responsible for the appointment and dismissal of members of the management board (para 84(1) AktG). The management board has to report to the supervisory board on the matters set out in paragraph 90 AktG. The chairperson of the supervisory board of a German listed company is recommended to maintain regular contact with management board and its chairperson, and consult that person on strategy, business development and risk development in the undertaking (see para 5.2 of the Corporate Governance Code). Paragraph 5.2 also recommends that the chairperson of the supervisory board is informed by the chairperson of the management board without delay of important events which are essential to the assessment of the situation and development as well as the management of the undertaking. The chairperson of the supervisory board shall then inform the supervisory board, and if required, convene an extraordinary meeting of that board. These recommendations are clearly intended to facilitate the flow of information from the management board and its chairperson to the supervisory board and its chairperson. This has not always happened satisfactorily in the past.

According to paragraph 111(1) AktG, the supervisory board has the task of supervising the management of the company. Such supervision has not always taken place satisfactorily where the board has consisted of a large number of members. Such boards may be favoured by trade unions, because they obtain a larger number of representatives therein. Furthermore, the members of supervisory boards have sometimes previously held managerial positions with the same company. The chairman of the supervisory board has thus sometimes previously held the post of chairman of the management board. There may in such cases be reason to doubt whether such members of the supervisory board will exercise sufficiently independent judgment.

The tasks of the supervisory board are further specified in paragraph 111(2) $A k t G$, which mention, inter alia, the inspection and examination of the books and records of the company. The board is also empowered by paragraph 111(1) $A k t G$ to appoint the auditor to audit its annual and consolidated accounts. This provision owes its origin to the Control and Transparency Act 1998. Paragraph 111(3) provides that the supervisory board, acting by a simple majority, may call a general meeting whenever the interests of the company so require. Paragraph 111(4) AktG, provides that managerial tasks cannot be conferred on the supervisory board, but the statutes or the board must stipulate that certain transactions can only be entered into with its consent. If such consent is refused, such refusal may be overridden by the general meeting (which may be called at the request of the management board), by a majority of at least three quarters of the votes cast.

The power given to the supervisory board to represent the company in and out of court as against the members of the management board by paragraph $112 \mathrm{Akt} G$ does not only extend to claims against existing members of the management board but also against former ones. Such claims may involve expenses claimed by a member of the management board, or claims in respect of an agreement concluded with him to make provision for dependents. The supervisor board may well be reluctant to make claims against members of the management board, because the brining of such claims may sometimes indicate that the supervisory board has not carried out its supervisory tasks satisfactorily. Actions against members of the supervisory board may be brought by the management board.

It follows from paragraph 110 and $111 \mathrm{Akt} G$ that the supervisory board has important functions in relation to the company's accounts.

\section{Duties and liabilities}

Paragraph 116 provides that paragraph 93 regarding the duty of care and responsibility of the members of the management board shall apply by way of analogy to the duty of care and responsibility of the supervisory board. Further, similar criminal liabilities are imposed on members of the management board and the supervisory board by paragraphs 399 (false statements) 400 (misrepresentation) and 404 (breach of duty of confidentiality). German law governing the assertion of the company's damages claims against members of the management or supervisory boards by members of the company is unsatisfactory in several respects. Such claims could not until recently be asserted unless the aggregate holdings of the claimant shareholders exceed onetwentieth of the share capital or 500,000 euros in value. Such claimants may secure the appointment of special representatives by the court if there are facts which justify the grave suspicion that the company suffered a loss through dishonesty or serious breaches of the law or the statutes (para 147(3) $A k t G$ ). A recent amendment of the law, which will come into force on November 1, 2005 (2004 Act on the Furtherance of Corporate Integrity and the Redemocratisation of the Rules governing Shareholders' Claims) will reduce these amounts to 1 per cent of the share capital or 100, 000 euros. 
The present rules relating to costs under German law are somewhat unsatisfactory: the plaintiff has to bear all the costs and risks of brining the action. An unsuccessful shareholder does not only have to bear his or her own costs and those of their lawyer but also those of the opposing party (para 147(4) $A k t G$ ). An alteration in the present position relating to costs has been suggested and will remove the risk of costs from the plaintiff as soon as the action has been admitted by the court, as also has the abolition of the present requirement for a special representative. It has also been suggested that there should no longer be any need for an urgent suspicion of a loss through dishonesty or gross violations of the law, but simply a suspicion of such contingencies before an action might be brought. It is clear that German law is still rather undeveloped as far as derivative actions are concerned,

\section{FINAL REMARKS}

It has been suggested by Professor Hopt that German companies should be given a choice between adopting a single and a double board system (see Professor K. Hopt and P C Leyens, Board Models in Europe, European Corporate Governance Institute 2004). For political reasons, such a choice is unlikely to be made available, except in the limited context of the European Company. The system of codetermination in the supervisory board now appears to be deeply entrenched in German political and social traditions, whatever disadvantages it may have, which are alleged to include making large German companies unwelcome to foreign investors.

It appears difficult, owing to the opposition of trade unions, to enact legal provisions providing for supervisory boards having fewer members or for the reduction in the percentage of employee participation.

As already indicated, it appears difficult at present for members of a German company to bring a derivative action against members of one of its boards. This remains true despite recent changes in German law. The rules relating to the duties of members of their boards may be unclear in certain respects, and perhaps to require further codification. Certain of the provisions of the Corporate Governance Code may well be given statutory authority. This Code is revised each year.

\section{Frank Wooldridge}

Formerly Adjunct Professor, University of Notre Dame 